\title{
THE IMPACT OF EXPERT OPINION IN CONSUMER PERCEPTION OF
}

\section{WINES}

\section{INTRODUCTION}

In the wine world, experts' opinions reach the public through various means. Wine competitions, for example, are held the world over and the awards subsequently feature on wine labels. Wine ratings are regularly published in both the specialized and general press and more personal recommendations can be obtained from restaurant sommeliers. This wealth of information makes it easier for consumers to judge wines.

Product evaluations involving several different product options often leave consumers with a complicated task. Consumers in many markets reduce their uncertainty and accelerate their decision-making through consultation with a wide variety of recommendation sources, the most common of which are person-to-person information channels (Andersson, 2004; Harvey et al., 2000; Price and Feick, 1984; Kiel and Layton, 1981). In general, the opinions of friends and relatives or local retailers and other professionals such as financial analysts, doctors, cinema critics or enologists are valued and welcomed by consumers. Research on the film industry, for example, shows that films critics’ reviews are highly useful (Holbrook, 1999), particularly in boosting ticket sales for films in the mature stage of the lifecycle (Eliashberg and Shugan, 1997). More recently, online users' reports and star ratings have become an important source of product-quality information (Mueller et al., 2009; Chevalier and Mayzlin, 2006).

The literature shows that consumer response to personal information sources varies with the type of product. Nelson (1974) proposed a classification of goods in terms of the 
nature of their attributes: whether they are predominantly search attributes (that consumers can examine prior to purchase) or experience attributes (that they can verify only after sampling). Thus, some researchers analyze the relative impact of personal information sources with respect to search goods (cars, hi-fi systems, computers and calculators) and experience goods (cereal bars, frozen pizzas and wine) (House et al.,2008; Fitzsimons and Lehmann, 2004; Senecal and Nantel, 2004; Rosen and Olshavsky, 1987). Most of the related research, however, focuses on experience goods (films, homes or restaurants) (Gershoff et al., 2001; Gershoff and West, 1998; West and Broiarczyk, 1998), precisely because it is in choices involving experience goods that consumers are most sensitive to recommendations (Senecal and Nantel, 2004; Jain and Posavac, 2001; King and Balasubramanian, 1994; West and Broniarczyk, 1998). The difficulty of verifying the quality of experience goods prior to purchase means that, to avoid the disappointment of finding a large gap between expected and actual quality, consumers have to rely more heavily on recommendations than they would in the case of a search good. Duhan et al. (1997) also distinguish between different types of personal information sources. Their findings suggest that consumers tend more frequently to use more distant (or weak-tie) sources, such as expert opinions, when researching the technical or performance aspects of a product, but turn to strong-tie sources (friends and relatives) when evaluating aesthetic attributes.

This paper takes a deeper look into the effect of "weak-tie" personal information sources, particularly the opinions of experts or critics regarding experience goods, in this case, wine. This remains a topic of prime interest to both the academic and the business worlds. Scientific research into the effect of expert judgments on consumer perceptions is still scant (Gershoff et al., 2001; West and Broniarczyk, 1998; Eliashberg and Shugan, 1997) and businesses also need to assess the factors underlying its impact, 
given that the influence of expert judgment can be as crucial as quality to a product's success.

Despite its importance, however, different experts often give conflicting advice (Bolger and Wright, 1994; Shanteau, 1992). The degree of consensus among experts generally has an impact on the credibility of their opinions and consumer response towards them (Boor, 1990). The more contradictory the information, the less likely it is to be believed (Breakwell and Barnett, 2003). In relation to this, Mueller et al. (2009) obtained that experts influence consumers more strongly when a number of them coincide in giving a product a high quality rating, whereas low quality ratings tend to be disregarded no matter how strong the agreement among experts.

The mode of information presentation may also mediate the effect of experts' judgments. A complex judgment may not always be understood by consumers because of the greater cognitive effort required to process the information (Payne et al.,1993) while too simple a judgment may be disregarded because it gives too little information. Finally, consumer characteristics, such as the amount of wine knowledge, may modify the impact of recommendations, given that the capacity to assess a judgment depends on the consumer's experience and prior knowledge of the product category concerned (Andersson, 2004).

The aim of this paper is to apply an experimental design to evaluate the possible impact of expert judgments or recommendations on consumers' evaluations of wine. We also consider the effect of the level of expert consensus, the complexity of the information provided and the prior knowledge of the consumer. 
The main feature that distinguishes this paper from the previous literature is that it integrates all three moderating effects in a single experiment. While some previous studies have taken into account the level of consensus in the information provided (Mueller et al., 2009; Dean and Shepherd, 2007; Fitzsimons and Lehmann, 2004; Gershoff et al., 2001; West and Broniarczyk, 1998) and others have included consumer characteristics, such as the consumer's amount of category knowledge (Senecal and Nantel, 2004; Strebel et al.,2004; Andersson, 2004; Duhan et al., 1997; Fitzsimons and Lehmann, 2004; Rosen and Oshavsky, 1987), this paper enlarges the scope of the analysis by including another characteristic of information sources, i.e., the complexity or amount of expert information revealed.

The remainder of the paper proceeds as follows: first, we present the conceptual framework and the hypotheses regarding recommendations. We then describe the experiment designed to test the hypotheses and present the results. We conclude with a discussion of the main findings and the identification of areas for future research.

\section{THEORETICAL BACKGROUND AND HYPOTHESES}

Figure 1 illustrates the research model. It is followed by a description of the expected effects of the information provided by experts (including level of consensus and complexity) and the individual's own category knowledge on consumer wine ratings.

\section{INSERT FIGURE 1 ABOUT HERE}

Given the diversity of attributes associated with agri-food products, their quality is perceived as a multi-dimensional construct involving both intrinsic and extrinsic cues (Poole et al., 2007; Grunert, 1997; Verdú et al., 2004). Extrinsic cues relate to the product but are not physically a part of it (Olson, 1977; Zeithalm, 1988). They include 
aspects such as brand name, brand image and packaging. Consumers are able to evaluate these cues from the available information. The intrinsic cues associated with a product are its physical characteristics (Olson, 1977; Olson and Jacoby, 1972), which consumers can only judge through their own experience. They include taste, color and texture in the case of drinks (Zeithalm, 1988). Mueller (2004) finds a third type, credence cues, which cannot be judged even after consumption, such as health benefits, environmental benefits and production methods.

Wine is more difficult than other agri-food products for consumers to evaluate, because its intrinsic cues are much more numerous than its extrinsic or credence cues. When purchasing wine, consumers use any available information about the extrinsic and credence attributes of the wine in order to infer its quality. However, only highly involved wine drinkers are able to understand the way in which certain extrinsic and credence attributes, such as the region, the variety of grape, and the winemaker, interact to determine the flavor of the wine (Lockshin et al., 2006).

In the light of these characteristics, professional wine tasters play a major role in the consumer decision-making process by reporting their experience and giving their opinion on those aspects of a wine that extrinsic cues cannot convey (Senecal and Nantel, 2004).

The limited capacity of the human mind to process information (Payne et al., 1993; Bettman, 1979) and the difficulty of evaluating experience products before purchase lead consumers to rely on recommendations to simplify decisions concerning this type of product (Mueller et al., 2009; Senecal and Nantel, 2004; Jain and Posavac, 2001; King and Balasubramanian, 1994; West and Broniarczyk, 1998). Swaminathan (2003) argues that the more complex the product, the more useful recommendations become, 
and Jain and Posavac (2001) obtain that information sources describing experience attributes persuade consumers more effectively than those reporting on search attributes.

The prevailing evidence suggests that expert opinion plays a major role in consumer decision making (Swaminathan, 2003; Häubl and Murray, 2003; Duhan et al., 1997; Rosen and Olshavsky, 1987, among others) unless the consumer is reluctant to accept advice (Fitzsimons and Lehmann, 2004; Tormala and Petty, 2004). In the category that concerns us, Lockshin et al.(2006) showed that wine labels featuring awards (medals) influenced wine purchase decisions, while Mueller et al. (2009) found that all types of information shown to consumers, star quality ratings in particular, but also experts' ratings, sensory descriptions and awards had a positive influence on wine purchase choices. Thus, expert product ratings are more likely to influence consumer evaluations of a product such as wine. Hence, our first hypothesis is:

Hypothesis 1. The wine ratings of consumers with access to expert reports will move in the direction of the wine expert's ratings, whether higher or lower than the consumer's.

Given previous evidence of the influence of personal characteristics on consumer response to recommendation sources, we consider consumers' prior knowledge of the product category as a decision-making variable (Cortiñas et al., 2009; Senecal and Nantel, 2004; Strebel et al., 2004; Duhan et al., 1997; Fitzsimons and Lehmann, 2004; Rosen and Oshavsky, 1987; Yen et al., 2008) that affects the way they interpret available information and evaluate options (Andersson, 2004; Maheswaran and Sternthal, 1990; Maheswaran, 1994; Bettman et al.,1998; Perrouty et al., 2006; Drichoutis et al.,2005; Lusk et al., 2004; Alba et al.,1991). 
The literature defines the concept of prior knowledge in terms of the individual's experience and familiarity with the product. It has been the subject of extensive research (Alba, 1983; Alba and Hutchinson, 1987; Brucks, 1985; Herr, 1989; Murray, 1991; Park et al., 1994; Rao and Monroe, 1988; Sujan, 1985; Cortiñas et al., 2009) and commonly serves to refer to recallable information that is examined prior to consulting external sources.

Drawing on prospect theory (Kahneman and Tversky, 1979), we can assume that a consumer with a high level of knowledge about a particular experience good will judge it by a higher standard than an occasional consumer who knows little about it, because the former's level of reference is higher. Thus, a rating made by a knowledgeable consumer will be lower than that made by a less knowledgeable one, because expectations are based on past experience (Broniarzcyk and Alba, 1994). In short, prior knowledge can affect consumer wine ratings, since the capacity to evaluate a product depends on prior experience and knowledge of the product category. Thus, we establish that:

Hypothesis 2. Consumers with a knowledge of wine give lower ratings than those whose wine knowledge is scant.

Knowledge not only influences product ratings, it also influences the potential impact of recommendations concerning experience goods. The uncertainty associated with experience goods varies inversely with knowledge of the product category thus increasing the perceived risk associated with their purchase (Dowling and Staelin, 1994; Roselius, 1971). As their knowledge increases, consumers become more confident of their ability to judge experience attributes (Marks and Olson, 1981). This makes them less likely to disregard them in their product ratings (Park and Lessig, 1981; Rao and 
Monroe, 1988) and more likely to disregard opinions that run counter to their own experience-based judgments (Fitzsimons and Lehmann, 2004).

The third hypothesis we establish, therefore, is:

Hypothesis 3.The less consumers know about wine, the more they will be influenced by expert opinion

The impact of recommendations strengthens with the credibility or personal experience of the source. Contradictory information reduces the credibility of the information presented, increases perceived risk, creates uncertainty and undermines the influence of the message (Dean and Shepherd, 2007; Breakwell and Barnett, 2003; Smithson, 1999; Viscusi, 1997; Meyer, 1981). Although some disagreement between experts may be desirable in order to stimulate debate, a high degree of consensus is necessary if consumers are to find them credible and value their opinions (Boor, 1990). Consensus also increases their power of persuasion (Petty and Wegener, 1998). According to West and Broniarczyk (1998), consumer evaluations depend on consensus between experts, particularly with respect to experience goods. In the wine category in particular, as mentioned in the introduction, Mueller et al. (2009) have shown that experts' opinions influence consumers more strongly when the ratings are high and show low variance. This allows the assumption that consumers pay more heed to experts' opinions when they show similarity, while tending not to notice them or to disregard them when there is disparity. This leads us to the following hypothesis regarding the degree of consensus between experts:

Hypothesis 4. There is positive correlation between the degree of consensus among experts' wine ratings and the degree of impact on consumers. 
To conclude, our analysis considers an additional characteristic of recommendation sources, i.e., the amount-of-information effect and to what extent its impact varies with the consumer's level of knowledge.

The human capacity to process information has its limits (Bettman, 1979). Information overload results in dissatisfaction and/or the postponement or even abandonment of the decision to purchase (Jacoby et al., 1974). Much research has been devoted to measuring the perception of information overload (Jacoby et al., 1974; Lussier and Olshavsky, 1979; Payne, 1976) in an attempt to determine the number of attributes that consumers are able to process simultaneously before starting to feel the effects of information overload. Malhotra (1982), for example, found that consumers experience information overload when confronted with information about more than fifteen attributes. This effect is heightened if the consumer is unfamiliar with or inexpert in the product category concerned (Chase and Simon, 1973; Huffman and Kahn, 1998).

Hayes-Roth (1977) and Marks and Olson (1981) showed that growing knowledge helps to develop people's cognitive structures and the ability to create mental schemas. Consumers with more knowledge are able to process information at a deeper and more detailed level than those with less knowledge (Selnes and Troye, 1989; Ballester et al., 2008). Johnson and Russo (1984) and Brucks (1985) found a positive association between prior knowledge and the ability to process new information efficiently. Furthermore, the greater their knowledge of a product category, the more attributes consumers are able to incorporate into their evaluation of the product and the choice process (Chocarro et al., 2012; Andersson, 2004; Rao and Monroe, 1988; Mitchell and Dacin, 1996; Perrouty et al., 2006) and the greater their receptiveness towards more complex technical information. The scarcer their knowledge, the more receptive they 
will be to a simple message (Maheswaran and Sternthal, 1990). This allows the prediction that consumers' knowledge levels should influence the use they make of the quantity and quality of expert information. The scanter understanding of consumers with little product category knowledge will prevent them from assimilating large quantities of complex information. Thus, in general terms, we hypothesize H5a for the main effect and $\mathrm{H} 5 \mathrm{~b}$ for the interaction effect:

Hypothesis 5a. The degree to which consumers' wine ratings are influenced by expert reports diminishes with the complexity of the information they contain.

Hypothesis 5b: The effect of expert opinion on wine evaluation of highly knowledgeable consumers is increased by the complexity of expert reports they receive.

\section{THE RESEARCH METHOD}

\section{Subjects and Design}

An external market research company recruited a random selection of 164 subjects. Participants were recruited from the vicinity of the establishments (wine-outlets, bars, and market research facilities) where the wine-tasting and the survey were to take place and invited to take part in the experiment. The response rate was high (about 80\%).This study uses a nested within-subject design including 2consumer knowledge levels(low/high) $\times 2$ consumer treatments: (report shown, report not shown) $\mathrm{x}$ 2levels of expert consensus (high/low) x 2 levels of information complexity (summary/ detailed report) between-subject experimental design. Table 1 summarizes the experimental design.

INSERT TABLE 1 ABOUT HERE 


\section{Materials}

\section{Wines}

The study used six different young wines from Navarra, a Spanish wine-producing region. All six alternatives were of the same type (red), vintage (2005) and designation of origin (Navarra). This number of alternatives is common in other studies of this type (Schiefer and Fischer, 2008; Sauvageot et al., 2006; Frost and Noble, 2002) and was considered appropriate because several alternatives were needed to enable us to analyze the effect of the recommendations while at the same time observing the effect of label revealed versus label concealed. Thus, bottles 1 and 2, both containing wine made from tempranillo grapes, were tasted with the labels and retail prices revealed. Bottle 1, Piedemonte, has high brand awareness and a reputation for quality in the region. Bottle 2, Aroa, has quite low brand awareness. Bottles 3 to 6 were all tasted blind but with the retail price revealed. Bottle 3, Palacio de Sada, is made from grenache noir grapes, bottle 4 held the same wine as bottle 1 , bottle 5 is a Piedemonte made from merlot grapes. Bottle 6 held the same wine as bottle 2. Figure 2 shows the different wines considered in the study together with their prices.

\section{INSERT FIGURE 2 ABOUT HERE}

\section{Reports}

Prior to the experiment, ten experts, including 7 enologists and 3 reputed local sommeliers, ranging in age between 26 and 55, were invited to a 6-bottle wine tasting, and asked to provide critical reviews. The tasting took place in a purposely- designed venue to enable the experts to concentrate on the wines. Experts' ratings were given individually and in isolation from the rest. 
Using the information provided by the experts, we wrote the reports shown in the appendix. The appendixes report results of the wine experts' evaluations of the six wine stimuli used in this study, en donde se puede apreciar: the average score for each wine, the level of consensus between the experts and the complexity of the information provided.

For experimental purposes, we need some level of discrepancy between consumer and expert ratings to be able to detect and measure the effect of expert opinion on consumer evaluations.

Therefore, more extreme values were introduced as the expert ratings for two of the wines (bottles 3 and 5) while the true expert ratings (which were closer to an objective wine-quality score) were maintained for the remaining four. Since the intention was also to control for the label effect by presenting labelled/blind pairs (pairs 1/4 and 2/6), the ratings for wines 3 and 5 were adjusted to control for the effect of this modification on the impact of the report. Figure 2 also shows the ratings for each wine and the adjusted ratings for wines 3 and 5 .

In order to test the consensus effect, the responses were tabulated to show the experts' average ratings (the global average rating for each wine) and a consensus index was derived from the variance. The variance measure used to assess the level of consensus is consistent with that used by other authors for this purpose (West and Broniarczyk, 1998; Ganzach, 1995; Meyer, 1981). In this study, however, the variance values were calculated in such a way as to make their meaning more obvious to the participants in the experiment. Thus, the consensus index takes a value of 10 for zero variance (high consensus) and 0 for the highest possible variance (low consensus). 
Finally, to test the complexity effect, we prepared two types of report, one detailed, the other more concise. Different combinations of format and level of consensusresulted infour different reports for the six wines: 1) a detailed attribute assessment with high consensus data (the full report, which is included in the appendix): 2) a concise attribute assessment with high consensus data (the concise report, also included in the appendix); 3) a detailed attribute assessment with low consensus data (reporting one third of the high consensus in the complete report: the modified full report), and 4) a summarized attribute assessment with low consensus data (reporting one third of the high consensus in the concise report: the modified concise report). The experts' reports were construed as numerical ratios because numerical data are easier to differentiate and recall than verbal data (Viswanathan and Childers, 1996) and may therefore have a greater impact when read by consumers.

\section{Procedure}

The study took place in November 2006 in the city of Pamplona, capital of Navarra, Spain. An external market research company recruited a random sample of 164 participants. Eligible recruits were invited to enter and answer a short questionnaire in order to assess their product knowledge level. Subjects were sorted on the basis of their self-assessed wine knowledge (high or low) combined with an objective test of wine knowledge and experience ${ }^{\mathrm{i}}$.

Subjects were then randomly assigned to ten different test groups and invited to taste the 6 glasses of wine which were laid out on a special table covering showing the basic characteristics of the wines. Table 1 illustrates the allocation of subjects to the various groups for the experiment. 
Participants from eight of the ten groups were exposed, respectively, to one of the four different versions of the expert report on each wine. After reading the reports, which they kept on hand for further reference, the subjects tasted the wines. Each participant was given a folder containing paper, pencil and questionnaire and asked to taste the 6 wines. After trying each wine, participants had to fill in the questionnaire by giving an overall assessment and a rating for each different attribute on a 7-point Likert scale (the measures used in the analysis are the overall attribute scores for the different wines). Each participant was assisted by a trained interviewer to ensure correct understanding of all the questions. Bread and water were provided for respondents to cleanse their palates after tasting each wine.The wines were presented for tasting in random order as they had been for the experts. The two groups who were not shown any report were given the same questionnaire as the rest of the respondents. Table 2 presents some descriptive statistics for the sample.

\section{INSERT TABLE 2 AROUND HERE}

\section{Methodology}

This experiment enables us to obtain 6 result variables for each subject: one for each wine that was tasted. MANOVA testing was an option that would allow simultaneous analysis of the effects of the model in all six estimation equations. However, given that, except for the average rating for each wine, we did not expect the impact of the effects to differ across the six wines, we decided to estimate a single regression equation to facilitate a more parsimonious interpretation of the findings. In this estimation, we correct for autocorrelation of error terms in observations for individual subjects by using cluster-robust standard errors (e.g. Binder, 1983). 
The model takes the following form:

$$
\begin{gathered}
\text { ConsumerEvaluation }_{t i}=\sum_{i=1}^{6} \beta++\sum_{i=1}^{6} \beta \text { oi }_{1 i} \text { Report }_{t i}+\beta_{2} * \text { Knowledge }_{t}+\beta_{3} \\
* \text { DReport }_{t} * \text { Knowledge }_{t}+\beta_{4} * \text { DReport }_{t} * \text { Consensus }_{t} \\
+\beta_{5} * \text { DReport }_{t} * \text { Complexity }_{t}+\beta_{6} * \text { DReport }_{t} \\
* \text { Knowledge }_{t} * \text { Complexity }_{t}+\beta_{7} * \text { Sex }_{t}+\beta_{8} * \text { Age }_{t}
\end{gathered}
$$

Where:

t: Subject 1-164

$i$ : Alternative: 1-6

ConsumerEvaluation $_{t i}$ : Subject t's evaluation of wine i

Knowledge $e_{t}: 1$ if the subject belongs to the highly knowledgeable group and 0 otherwise.

Report $_{t i}$ : Rating for wine I in the report (0, if subject $\mathrm{t}$ was shown no report)

DReport $_{t}$ : if subject t was shown a report, 0 otherwise

Consensus $_{t}: 1$ if the subject received low consensus data, 0 otherwise

Complexity $_{t}: 1$ if the subject was shown the full report, 0 otherwise

$\operatorname{Sex}_{t}$ : Control variable for sex of subject

$A g e_{t}$ : Control variable for age of subject 


\section{RESULTS}

The 5 hypotheses were tested by linear regression analysis of 948 scores (164 subjects $\mathrm{x}$ 6 wines), the results of which are given in Table 3. This regression accounted for $93.6 \%$ of the variance, which we deemed to be satisfactory.

\section{INSERT TABLE 3 ABOUT HERE}

The first notable finding is the statistical significance of all the estimated coefficients (the t-Student statistic is greater than 2), for the average ratings of each wine given by those subjects who had been shown none of the reports and whose wine knowledge was considered to be low. Differences can be seen between the average ratings given by this group, from whom bottle 4 obtained the lowest average rating $\left(\beta_{o, 4}=4.606\right)$ and bottle 6 the highest average rating $\left(\beta_{o, 6}=5.061\right)$. A label effect can also be observed. Bottle 1 (high brand recognition, price 2.70€) receives higher ratings than bottle 4 (tasted blind) (4.902 versus 4.606), although both contain the same wine. The opposite occurs with bottle 2 (low brand recognition, price 4.95€). This receives lower average ratings than bottle 6 (4.970 versus 5.061), which is the same wine tasted blind.

The estimated coefficients of correlation between the average ratings of the 6 bottles across the eight groups of subjects who saw a version of the expert report and those who saw none are negative and significant at the $5 \%$ level for bottles $3\left(\beta_{1,3}=-1.049\right)$ and 6 $\left(\beta_{1,6}=-0.581\right)$, and at the $10 \%$ level for bottles $2\left(\beta_{1,2}=-0.598\right)$ and $4\left(\beta_{1,4}=-0.418\right)$.The negative sign of these coefficients shows that the estimated ratings of the subjects who had some information from the reports are lower than the predicted ratings of those who had none. Therefore, the average ratings vary (in four of the six bottles, at any rate) as a function of access versus no access to information from the wine experts. Hypothesis 1 
states that the wine ratings of consumers who are exposed to experts' opinions will differ from those of the ones who are not. This confirms our first hypothesis.

Furthermore, continuing with the analysis of the average ratings given by subjects who had read a version of the report versus those who had read none, it can be seen that the highest significant negative impact of expert opinion on consumer ratings was found for bottle $3\left(\beta_{0,3}(4.879)+\left(\beta_{1,3}(-1.049)=3.83\right)\right.$. That is, subjects who were exposed to information from the experts' report gave bottle 3 a $21.5 \%$ lower average rating than those who were not. It is worth recalling that bottle 3 is one of those for which the ratings were later modified. The experts’ ratings were reduced by 1.5 points, making this the lowest-rated wine of all those presented. As advanced in the research materials, the experts' ratings were altered in order to heighten their impact, because otherwise the effect would have been more difficult to detect. It is hardly surprising, therefore, that the report has more impact when there is more difference between the real and the adjusted rating. This additional evidence of the influence of wine experts' recommendations provides further support for hypothesis 1 .

Hypothesis 2 states that consumers who are highly wine-knowledgeable will give lower ratings than those with little knowledge.To test this hypothesis, we need to compare the ratings of the 5 high-knowledge groups with those of the 5 low-knowledge groups. The results, shown in Table 3 , enable us to confirm our hypothesis. $\beta_{2}=-0.870$ indicates that the estimated rating of the high-knowledge subjects is lower than that of the lowknowledge subjects.

The third hypothesis predicts that experts' opinions have more influence on lowknowledge consumers. To test the effect of access to a report and knowledge of wine (or lack of it), we compare the ratings of the four groups who exhibited a high knowledge 
of wine and had access to a version of the experts' report with those of the other six groups. The $\beta_{3}$ parameter coefficient is positive and significant (0.673). Given that the report has a negative effect (reduces the consumers' ratings) this positive $\beta_{3}$ parameter significantly attenuates the impact of the report on the high-knowledge group. We are therefore able to conclude that the report has a greater impact on the low-knowledge group, thereby confirming hypothesis 3, which stated that the more wineknowledgeable the consumer, the less he/she is influenced by experts’ opinions.

Hypothesis 4 states that there is positive correlation between the degree of consensus among experts' wine ratings and the influence of their opinions on consumers. To test this hypothesis, we compare the ratings of subjects from the four groups who were shown the report containing low-consensus data with those of the remaining groups. In this case, the non-significant coefficient $\beta_{4}=-0.045$ prevents us from telling whether the level of consensus among experts has any impact on the credit consumers give to the reports. Hypothesis 4 therefore remains unconfirmed.

Finally, to test hypothesis5, which refers to the complexity of the information and relationship between this and consumer knowledge, we first need to compare the ratings given by the four groups of subjects who were shown the full detailed report with those of the remaining groups. Since no significant effects emerge, we are unable to confirm hypothesis 5 and no effect is found for the complexity of the information provided. 
Two control variables (sex and age) are included in the model, but neither shows a significant coefficient.

\section{CONCLUSIONS, IMPLICATIONS AND FUTURE RESEARCH}

The literature on consumer behaviour has often discussed the impact of recommendations on consumer preferences and has highlighted the potential importance of the role played by critical reviews and recommendations in shaping consumers' evaluations of certain products, although the effect is not always apparent and tends to depend on the context and type of product. Well-known and influential critics, such as Robert Parker of The Wine Advocate, Steve Tanzer of The International Wine Cellar or Clive Coates of The Wine can cause wine sales to rocket or plummet. The views of these critics are also important for wine retailers who can use their ratings to inform their advertising and pricing decisions (Bentzen and Smith, 2008), and for consumers, who consult their reviews when deciding what to buy, sometimes following their recommendations to the letter (Dewald, 2008).

We have been able to confirm the effect of the information received by the consumers on their evaluation of the products. Recommendations in the form of experts' overall ratings for each bottle, made available during the wine tasting, have an impact on the consumers' ratings. This is consistent with the findings of Mueller et al. (2009) for the product category that concerns us. Therefore, the industry's efforts with this information may have the desired effect on consumers.

Subjects with more knowledge of wine gave lower ratings than those with less. This is because they judge wines by a higher quality standard, which tends to lower their scoring. This is something for wine producers and retailers to bear in mind, given that 
so-called "wine buffs" are among those most likely to be asked by family and friends for recommendations on what to buy. They consider themselves sufficiently capable of forming their own opinions of the product even when they do not coincide with those of the experts. Hypotheses 1, 2 and 3 thus stand confirmed.

We can therefore assume that the market contains several consumer segments with a variety of behavioral patterns requiring different forms of marketing approach, which, in turn, require adaptation of management policy. A greater marketing effort appears to be required, for example, to improve the ratings given by the high-knowledge segment, a task made all the more difficult by their lower sensitivity to experts’ opinions.

One way to achieve this might be to feature experts' ratings in wine displays in order to give customers an impression of objective quality. Obviously, these cues must be reliable, since they could backfire if they fall short of customers' expectations. As a further alternative, and with a view to assisting more knowledgeable consumers with their purchase choices, we would recommend maintaining a highly-qualified sales force to provide opportunities for extended personal exchanges with individual customers. In the catering channel, which is so important to this product category, figures of influence, such as wine-waiters, may prove more persuasive to customers with a more serious interest in wine. Firms eager to capture this type of customer (sometimes defined as prescriptors) need to tailor their PR campaigns accordingly.

As well as their overall influence, this study aimed to investigate the impact of two other aspects of expert reviews, that is, the degree of consensus and complexity in the information they have to offer. Our empirical findings, however, failed to show that either has any relevance. The level of consensus among experts was not perceived by our subjects as a sign of reliability. There are two possible reasons for this. The first is a 
technical detail relating to the levels of consensus used in the questionnaire, which may have been too close to make much difference to consumers' own evaluations of the alternatives. The second has to do with an aspect of human nature, specifically, the willingness to process information. The subjects participating in this product comparison trial may have obtained sufficient guidance from the experts' average ratings and lacked enough further interest to take into account the degree of consensus when making their own evaluations. Past experience may also lead consumers to expect a lack of convergence in experts' opinions (Andersson, 2004) because, as Shanteau (1992) remarks, there is no unique truth and reality is like a "moving target". Thus, further research is needed regarding the impact of the degree of expert consensus on consumers' product evaluations (Dean and Shepherd, 2007; Gershoff et al., 2001; West and Broniarczyk, 1998).

As far as information complexity is concerned, we suspect that our experimental design failed to provide sufficient variation in this respect, given that the key detail (the overall rating) appeared at the beginning of both reports and subjects may have tended to disregard the rest of the information provided.

We have found that expert opinion is not the only factor that influences consumers, however, since certain extrinsic cues also play a role in determining consumers' product ratings. Brand and price, for example, can either improve or diminish the ratings of wines that score well in blind tastings. Experiments conducted by Monaco et al., (2004) in the pasta category also showed that open tasting (brand revealed) skewed the results, because consumers gave higher ratings to well-known brands and lower ratings to less well-known brands. This appears to suggest that in our case, when tasting bottle 1 blind (high brand recognition), consumers focused on the price (2.70€) and gave the wine a 
lower rating than when tasting it with brand revealed, because of the tendency to give higher ratings to well-known brands. Bottle 2 (low brand recognition) receives higher ratings when tasted blind (due to its high price tag) than when its low-recognition brand is revealed. It is clear, therefore, that brand and price information affected the ratings given by subjects whose wine knowledge was considered low and who were not shown any version of the experts' report and that brand is a non-sensory variable that is a determinant of consumer behavior in the drinks category. Our findings for brand effects reinforce those of other investigators (Guinard et al., 2001; Murray and Delahunty, 2000). This shows that wine is a product in which appraisal of the intrinsic attributes is heavily affected by extrinsic attributes, such as brand and expert opinion (Mueller et al., 2010; Siegrist and Cousin, 2009). Making this kind of information clearly visible in wine displays is therefore highly recommended.

As well as those already mentioned, the limitations of this study include some relating to its experimental nature and the research design. The tests placed the consumers in an artificial situation, in which they received the experts' reports while tasting the wines. This rarely occurs in consumer markets, where product testing is usually a postdecision, post-purchase process, the impact of which affects subsequent purchases. Analysis of the impact of expert opinion on subsequent product choice, while not addressed by this study, would be an interesting topic for future research. However, as already mentioned in our allusion to the catering channel, this study places the consumer in a situation more akin to that of a restaurant, where the wine waiter's comments can influence the consumer's appreciation of the wine being served.

Another limitation lies in the levels of factors considered. Richer results might be obtained by using a wider range of expert-consensus and information-complexity levels. 
Future studies should also consider whether experts' reputations and consumer attitudes

influence receptiveness towards expert opinion in the wine market.

\section{References}

Alba, J. W. (1983), “The effects of product knowledge on the comprehension, retention, and evaluation of product information.”In R.P. Bagozzi and A.M. Tybout (Eds.), Advances in consumer Research (pp. 577-580). Ann Arbor, MI: Association for Consumer Research.

Alba, J. W., andHutchinson, J. W. (1987),“Dimensions of consumer expertise”,Journal of Consumer Research, Vol. 13 No. March, pp. 411-454.

Alba, J. W., Hutchinson, J. W., andLynch, J. G. (1991),“Memory and decision making.” In H. H. Kassarjian and T. S. Robertson (Eds.), Handbook of Consumer Research (pp. 1-49). New York: Prentice Hall.

Andersson, P. (2004), “Does experience matter in lending? A process-tracing study on experienced loan officers' and novices' decision behavior”, Journal of Economic Psychology, Vol. 25, pp. 471-492.

Ballester, J., Patris, B., Symoneaux, R., andValentin, D. (2008), «Conceptual vs. perceptual wine spaces: does expertise matter?”,Food Quality and Preference, Vol. 19 No. 3, pp. 267-276.

Bentzen, J., and Smith, V. (2008), “Do experts ratings or economic models explain champagne prices?”,International Journal of Wine Business Research,Vol. 20No. 3, pp. 230-243.

Bettman, J. R. (1979), “Memory Factors in Consumer Choice: A Review”,Journal of Marketing, Vol. 43 No. 2, pp. 37-53.

Bettman, J. R., and Park, C. W. (1980), “Effects of prior knowledge and experience and phase of the choice process on consumer decision processes”.Journal of Consumer Research, Vol. 7 No. December, pp. 234-248.

Bettman, J. R., Luce, M. F., and Payne, J. W. (1998), "Constructive consumer choice processes”. Journal of Consumer Research, Vol.25 No. 3, pp. 187-217.

Binder, D. A. (1983), "On the variances of asymptotically normal estimators from complex surveys.” International Statistical Review, Vol. 51,pp- 279-292.

Bolger, F., and Wright, G. (1994),“Assessing the quality of expert judgment: issues and analysis”. Decision Support Systems, Vol. 11, pp. 1-24.

Boor, M. (1990), Reliability of Ratings of Movies by Professional Movie Critics. Psychological Reports, Vol. 67 No. August, pp. 243-257.

Breakwell, G.M., and Barnett, J. (2003), "The significance of uncertainty and conflict: developing a social psychological theory of risk communication". New Review of Social Psychology, Vol. 2, pp. 107-114.

Broniarczyk, S.M., and Alba, J.W. (1994), "Influence of prior beliefs, frequency cues, and magnitude cues on consumers' perceptions of comparative price data”. Journal of Consumer Research, Vol. 21 No. September, pp. 219-235.

Brucks, M. (1985), “The effects of product class knowledge on information search behavior”.Journal of Consumer Research, Vol. 12 No. June, pp. 1-16.

Cortiñas, M., Chocarro, R., and Elorz, M. (2009), “The impact of product category knowledge on consumer use of extrinsic cues. A study involving agrifood products". Food Quality and Preference, Vol. 20 No. 3, pp. 176-186. 
Chase, W.G. and Simon, H.A. (1973), “Perception in Chess”.Cognitive Psychology, Vol. 4 No.1, pp. 55-81.

Chevalier, J.A. and Mayzlin, D. (2006), « The effect of word of mouth on sales: online book reviews”. Journal of Marketing Research, Vol. 43, pp. 345-354.

Chocarro, R., Elorz, M., and Múgica, J. M. (2012), “Consumers’ Internal Categorization Structures. An Additive Tree Analysis”. European Journal of Marketing, Vol. 46 No. 6, pp. 760-789.

Dean, M., andShepherd, R. (2007), "Effects of information from sources in conflict and in consensus on perceptions of genetically modified food”. Food Quality and Preference, Vol. 18, pp. 460-469.

Dewald, B.W.A. (2008), "The role of the sommeliers and their influence on US restaurant wine sales”.International Journal of Wine Business Research,Vol. 20 No. 2, pp. 111-123.

Dowling, G.R., and Staelin, R. (1994), “A model of perceived risk and intended riskhandling activity”. Journal of Consumer Research, Vol. 21 No. June, pp. 119-134.

Drichoutis, A.C., Lazaridis, P., and Nayga, R.M. (2005), “ Nutrition knowledge and consumer use of nutritional food labels”. European Review of Agricultural Economics, Vol. 32 No. 1, pp. 93-118.

Duhan, D.F., Johnson, S.D., Wilcox, J.B., andHarrell, G.D. (1997), “Influences on consumer use of word-of-mouth recommendation sources”. Journal of the Academy of Marketing Science, Vol. 25No. 4, pp. 283-295.

Eliashberg, J., and Shugan, S. M. (1997), “Film critics: influencers or predictors?”. Journal of Marketing, Vol. 61 No. April, pp. 68-78.

Fitzsimons, G. J., and Lehmann, D. R. (2004), "Reactance to recommendations: when unsolicited advice yields contrary responses”. Marketing Science, Vol. 23No. 1, pp. 82-94.

Frost, M.B., and Noble, A.C. (2002), "Preliminary study of the effect of knowledge and sensory expertise on liking for red wines”. American Journal of Enology and Viticulture, Vol. 53 No. 4, pp. 275-284.

Ganzach, Y. (1995), “Attribute scatter and decision outcome: judgment versus choice”. Organizational Behavior and Human Decision Processes, Vol. 62 No. 1, pp. 113122.

Gershoff, A. D., Broniarczyk, S. M., and West, P. M. (2001), "Recommendation or evaluation? Task sensitivity in information source selection". Journal of Consumer Research, Vol. 28 No. December, pp. 418-438.

Gershoff, A.D., and West, P.M. (1998), "Using a community of knowledge to build intelligent agents”. Marketing Letters, Vol. 9 No. 1, pp. 79-91.

Guinard, J. X., Uotani, B., and Schlich, P. (2001), "Internal and external mapping of preferences for commercial lager beers: comparison of hedonic ratings by consumers blind versus with knowledge of brand and price". Food Quality and Preference, Vol. 12, pp. 243-255.

Grunert, K.G. (1997),"What's in a steak. A cross-cultural study on the quality perception of beef”. Food Quality and Preference, Vol. 8 No. 3, pp. 157-174.

Harvey, N., Harries, C. and Fischer, I. (2000), "Using advice and assessing its quality". Organizational Behavior and Human Decision Processes, Vol. 81 No. 2, pp. 252273.

Häubl, G., and Murray, K. B. (2003), "Preference construction and persistence in digital marketplaces: the role of electronic recommendation agents". Journal of Consumer Psychology, Vol. 13 No. 1\& 2, pp. 75-91. 
Hayes-Roth, B. (1977), “Evolution of cognitive structures and processes”. Psychological Review, Vol. 84 No. 3, pp. 260-278.

Herr, P. (1989), “Priming price: prior knowledge and context effects”. Journal of Consumer Research, Vol. 16 No. June, pp. 67-75.

Holbrook, M.B. (1999), "Popular appeal versus expert judgments of motion pictures". Journal of Consumer Research, Vol. 26 No. September, pp. 144-155.

House, L.A., House, M.C., and Mullady, J. (2008), "Do recommendations matter? Social networks, trust, and product adoption?”Agribusiness, Vol. 24 No. 3, pp. 332341.

Huffman, C. and Kahn, B. E. (1998),"Variety for Sale: Mass Customization or Mass Confusion?” Journal of Retailing, Vol. 74 No. 4, pp. 491-513.

Jacoby, J., Speller, D.E., and Berning, C.K. (1974), "Brand Choice Behaviour as a Function of Information Load: Replication and Extension”. Journal of Consumer Research, Vol. 1, pp. 33-42.

Jain, S.P., and Posavac, S.S. (2001), "Prepurchase attribute verifiability, source credibility, and persuasion”.Journal of Consumer Psychology, Vol. 11 No. 3, pp. 169-180.

Johnson, E., and Russo, J. E. (1984), "Product familiarity and learning new information”. Journal of Consumer Research, Vol. 11 No. June, pp. 542-550.

Kahneman, D., and Tversky, A. (1979), "Prospect Theory: an analysis of decision under risk”. Econometrica, Vol. 47 No. 2, pp. 263-292.

Kiel, G.C and Layton, R.A. (1981), "Dimensions of Consumer Information Seeking Behavior”. Journal of Marketing Research, Vol. 18 No. May, pp. 233-239.

King, M.F., and Balasubramanian, S.K. (1994), "The effects of expertise, end goal, and product type on adoption of preference formation strategy". Journal of the Academy of Marketing Science, Vol. 22 No. 2, pp. 146-159.

Lockshin, L.S., Jarvis, W., d'Hauteville, F., and Perrouty, J.P. (2006),“Using simulations from discrete choice experiments to measure consumer sensitivity to brand, region, price, and awards in wine choice”. Food Quality and Preference, Vol. 17 No. 3-4, pp. 166-178.

Lussier, D.A. and Olshavsky, R.W. (1979), “Task Complexity and Contingent Processing in Brand Choice”. Journal of Consumer Research, Vol. 6 No.2, pp. 154165.

Lusk, J.L., House, L.O., Valli, C., Jaeger, S.R., Moore, M., Morrow, J.L., et al. (2004), "Effect of information about benefits of biotechnology on consumer acceptance of genetically modified food: evidence from experimental auctions in the United States, England, and France”. European Review of Agricultural Economics, Vol. 31 No. 2, pp. 179-204.

Maheswaran, D. (1994), "Country of Origin as a Stereotype: Effects of Consumer Expertise and Attribute Strength on Product”. Journal of Consumer Research, Vol. 21 No. 2, pp. 354-365.

Maheswaran, D., and Sternthal, B. (1990), “The Effects of Knowledge, Motivation, and Type of Message on Ad Processing and Product Judgments”. Journal of Consumer Research, 17 No. June, pp. 66-73.

Malhotra, N.K., (1982), “Information Load and Consumer Decision Making”.Journal of Consumer Research, Vol. 8 No.4, pp. 419-430.

Marks, L.J., and Olson, J.C. (1981), “Toward a cognitive structure conceptualization of product familiarity”. In K. Monroe (Ed.), Advances in Consumer Research (pp. 145150). Ann Arbor, MI: Association for consumer research. 
Meyer, R. J. (1981). “A Model of Multiattribute Judgments under Attribute Uncertainty and Informational Constraint”. Journal of Marketing Research, Vol. 18No. November, pp. 428-441.

Mitchell, A. A., and Dacin, P. F. (1996), "The assessment of alternative measures of consumer expertise”. Journal of Consumer Research, Vol. 23 No. December, pp. 219-240.

Monaco, R. Di., Cavella, S., Marzo, S. Di., and Masi, P. (2004), “The effect of expectations generated by brand name on the acceptability of dried semolina pasta". Food Quality and Preference, Vol. 15, pp. 429-437.

Mueller, S. (2004), "The German wine law from an information economics perspective”. International Journal of Wine Marketing, Vol. 16, pp. 72-86

Mueller, S., Lockshin, L., Louviere, J., Francis, L. and Osidacz, P. (2009), "How does shelf information influence consumers' wine choices?” Wine Industry Journal, Vol. 24 No. 3, pp. 50-56.

Mueller, S. Osidacz, P., Francis, I. L., and Lockshin, L. (2010), “Combining discrete choice and informed sensory testing to determine consumer response to extrinsic and intrinsic wine attributes”. Food Quality and Preference, Vol. 21 No. 7, pp. 741754.

Murray, K.B. (1991),“A test of services marketing theory: consumer acquisition activities”. Journal of Marketing, Vol. 55No. January, pp. 10-25.

Murray, J. M., and Delahunty, C. M. (2000),“Mapping consumer preference for the sensory and packaging attributes of Cheddar cheese”. Food Quality and Preference, Vol. 11, pp. 419-435.

Nelson, P. (1974),“Advertising as Information”. Journal of Political Economy, Vol. 82No. 4, pp. 729-754.

Olson, J.C. (1977), "Price as an informational cue. Effects in product evaluation”. In A.G. Woodside, J.N. Sheth and P.D. Bennet (Eds), Consumer and industrial buying behaviour (pp. 267-286). New York: North Holland Publishing Company.

Olson, J.C., andJacoby, J. (1972), Cue utilization in the quality perception process. In M. Venkatesan (Ed.), Proceedings of the third annual conference of the association for consumer research (pp. 167-179). Iowa City: Association for Consumer Research.

Park, C. W., and Lessig, V. P. (1981), "Familiarity and its impact on consumer biases and heuristics". Journal of Consumer Research, Vol. 8 No. September, pp. 223-230.

Park, C. W., Mothersbaugh, D.L., and Feick, L. (1994), "Consumer knowledge assessment”. Journal of Consumer Research, Vol. 21 No. June, pp. 71-82.

Payne, J.W.(1976), “Task Complexity and Contingent Processing in Decision Making: An Information Search and Protocol Analysis”. Organizational Behaviour and Human Performance, Vol. 16, pp. 366-387.

Payne, J. W., Bettman, J. R., and Johnson, E. J. (1993),“The adaptive decision-maker”. New York: Cambridge, University Press.

Perrouty, J. P., d'Hauteville, F., and Lockshin, L. (2006), "The influence of wine attributes on region of origin equity: an analysis of the moderating effect of consumer’s perceived expertise”. Agribusiness, Vol. 22 No. 3, pp. 323-341.

Petty, R.E., and Wegener, D.T. (1998), "Attitude change: multiple roles for persuasion variables". In D.T. Gilbert, S.T. Fiske, and G. Lindzey (Eds.), The handbook of social psychology Vol. 1 (pp. 323-390). New York: McGraw-Hill.

Poole, N.D., Martínez-Carrasco, L. and Vidal, F. (2007), “Quality perceptions under evolving information conditions: Implications for diet, health and consumer satisfaction”. Food Policy, Vol. 32, pp. 175-188. 
Price, L., and Feick, L. (1984), “The role of interpersonal sources in external search: an informational perspective”. Advances in Consumer Research, Vol. 11, pp. 250-255.

Punj, G.N., andStaelin, R. (1983), "A model of consumer information search behavior for new automobiles”. Journal of Consumer Research, Vol. 9 No. March, pp. 366388.

Rao, A. R., and Monroe, K. B. (1988), "The moderating effect of prior knowledge on cue utilization in product evaluations”. Journal of Consumer Research, Vol. 15 No. 2, pp. 253-264.

Roselius, T. (1971), “Consumer rankings of risk reduction methods”.Journal of Marketing, Vol. 35, 5 pp. 6-61.

Rosen, D.L., and Olshavsky, R.W. (1987), "A protocol analysis of brand choice strategies involving recommendations”. Journal of Consumer Research, Vol. 14 No. December, pp. 440-444.

Sauvageot, F., Urdapilleta, I., and Peyron, D. (2006), "Within and between variations of texts elicited from nine wine experts". Food Quality and Preference, Vol. 17, pp. 429-444.

Schiefer, J., and Fischer, C. (2008),“The gap between wine expert ratings and consumer preferences”. International Journal of Wine Business Research,Vol. 20No. 4, pp. 335-351.

Selnes, F., and Troye, S. V. (1989), "Buying expertise, information search, and problem solving”. Journal of Economic Psychology, Vol. 10 No. 3, pp. 411-428.

Shanteau, J. (1992), “Competence in experts: the role of task characteristics”. Organizational Behavior and Human Decision Processes, Vol. 53, pp. 252-266.

Senecal, S., and Nantel, J. (2004), "The Influence of Online Product Recommendations on Consumers' Online Choices”. Journal of Retailing, Vol. 80 No. 2, pp. 159-169.

Smithson, M. (1999),“Conflict aversion: preference for ambiguity vs. conflict in sources and evidence”.Organizational Behavior and Human Decision Processes, Vol. 79, pp. 179-198.

Siegrist, M., and Cousin, M.E. (2009), "Expectations influence sensory experience in a wine tasting”. Appetite, Vol. 52 No. 3, pp. 762-765.

Strebel, J., Erdem, T., and Swait, J. (2004), “Consumer search in high technology markets: exploring the use of traditional information channels". Journal of Consumer Psychology, Vol. 14 No. 1 \& 2, pp. 96-104.

Sujan, M. (1985),“Consumer knowledge: effects on evaluation strategies mediating consumer judgments”. Journal of Consumer Research, Vol. 12, pp. 31-46.

Swaminathan, V. (2003), "The impact of recommendation agents on consumer evaluation and choice: the moderating role of category risk, product complexity, and consumer knowledge”. Journal of Consumer Psychology, Vol. 13 No. 1 \& 2, pp. 93101.

Tormala, Z.L., and Petty, R.E. (2004), "Source credibility and attitude certainty: a metacognitive analysis of resistance to persuasion". Journal of Consumer Psychology, Vol. 14 No. 4, pp. 427-442.

Verdú, A.J., Lloréns, F.J., and Fuentes, M.M. (2004), "Measuring perceptions of quality in food products: the case of red wine. Food Quality and Preference, Vol. 15, pp. 453-469.

Viscusi, W.K. (1997), “Alarmist decisions with divergent risk information”.The Economic Journal, Vol. 107, pp. 1657-1670.

Viswanathan, M., and Childers, T. L. (1996), "Processing of numerical and verbal product information.” Journal of Consumer Psychology, Vol. 5No. 4, pp. 359-385. 
West, P. M., and Broniarczyk, S. M. (1998), "Integrating Multiple Opinions: The Role of Aspiration Level on Consumer Response to Critic Consensus”. Journal of Consumer Research, Vol. 25 No. June, pp. 38-51.

Yen, S.T., Biing-Hwan L. and Davis, C.G. (2008), "Consumer knowledge and meat consumption at home and away from home”, Food Policy, Vol. 33, pp. 631-639.

Zeithaml, V.A. (1988), “Consumer perceptions of price, quality, and value: a means-end model and synthesis of evidence”. Journal of Marketing, Vol. 52 No. July, pp. 2-22. 
Figure 1: Research model

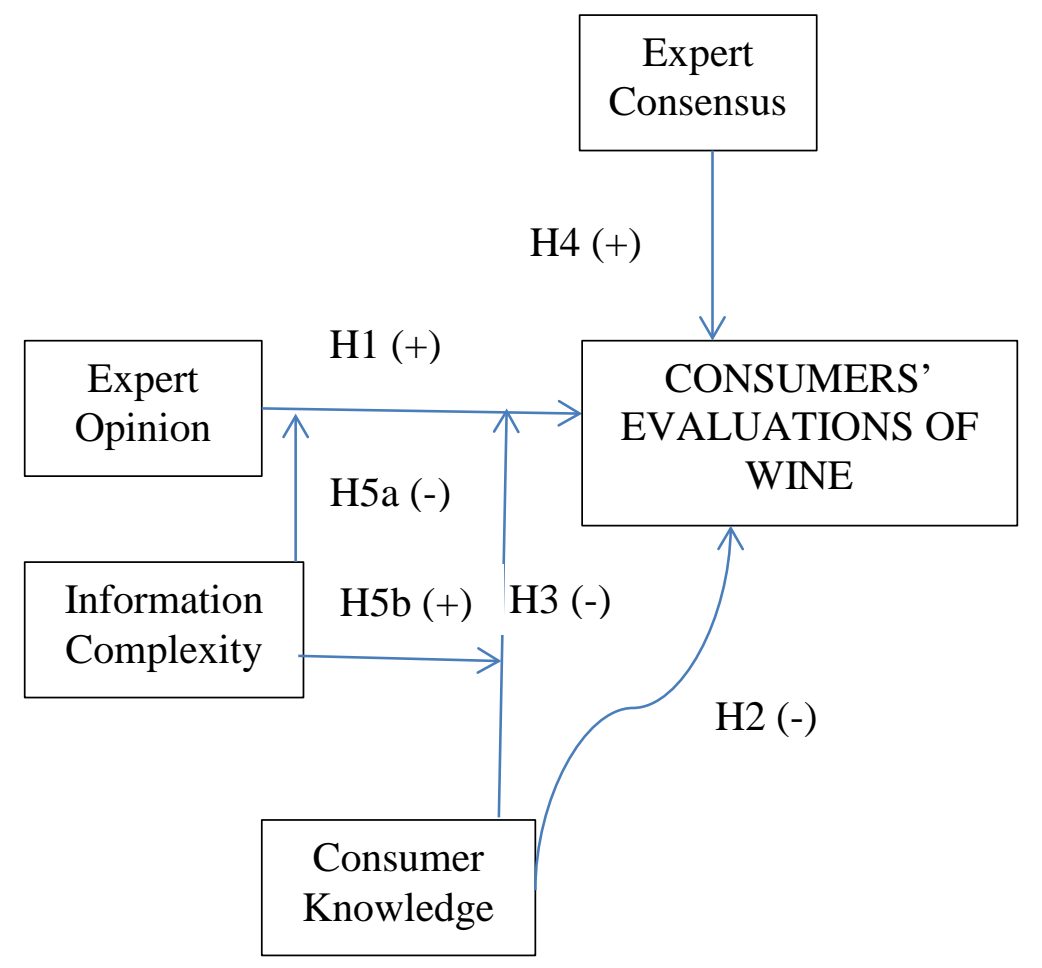

Figure 2: Wine stimuli

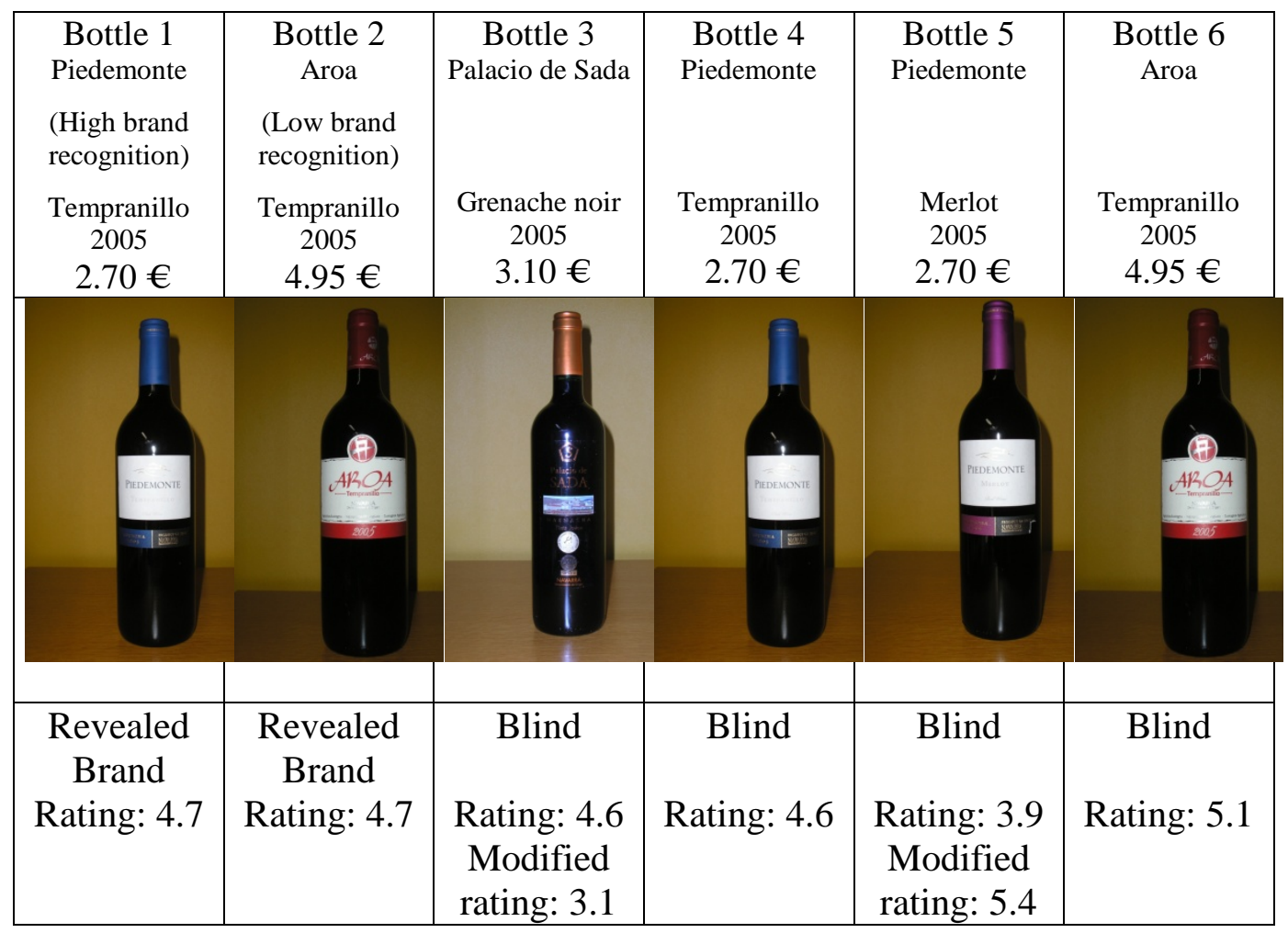


Table 1. Test Groups

\begin{tabular}{|c|c|c|c|c|c|c|c|}
\hline & & \multicolumn{4}{|c|}{ Report } & \\
\hline & & $\begin{array}{l}\text { No: Wine ratings } \\
\text { of consumers with } \\
\text { no } \quad \text { expert } \\
\text { information }\end{array}$ & $\begin{array}{l}\text { Yes: Wine } r \\
\text { with exp }\end{array}$ & $\begin{array}{l}\text { tings of consun } \\
\text { ert information }\end{array}$ & mers & & \\
\hline \multirow{4}{*}{ Knowledge } & \multirow[t]{2}{*}{$\begin{array}{l}\text { High: Wine ratings of } \\
\text { consumers with high } \\
\text { knowledge of wine }\end{array}$} & \multirow[t]{2}{*}{$\mathrm{N}=22$} & $\mathrm{~N}=15$ & \multicolumn{2}{|l|}{$\mathrm{N}=15$} & $\begin{array}{l}\text { High: Wine ratings of consumers } \\
\text { with expert information with high } \\
\text { consensus }\end{array}$ & \multirow{4}{*}{ Consensus } \\
\hline & & & $\mathrm{N}=15$ & $\mathrm{~N}=15$ & & $\begin{array}{l}\text { Low: Wine ratings of consumers } \\
\text { with expert information with low } \\
\text { consensus }\end{array}$ & \\
\hline & \multirow[t]{2}{*}{$\begin{array}{l}\text { Low: Wine ratings of } \\
\text { consumers with low } \\
\text { knowledge of wine }\end{array}$} & \multirow[t]{2}{*}{$\mathrm{N}=22$} & $\mathrm{~N}=15$ & \multicolumn{2}{|l|}{$\mathrm{N}=15$} & $\begin{array}{l}\text { High: Wine ratings of consumers } \\
\text { with expert information with high } \\
\text { consensus }\end{array}$ & \\
\hline & & & $\mathrm{N}=15$ & \multicolumn{2}{|l|}{$\mathrm{N}=15$} & $\begin{array}{l}\text { Low: Wine ratings of consumers } \\
\text { with expert information with low } \\
\text { consensus }\end{array}$ & \\
\hline & & & $\begin{array}{l}\text { Summary: } \\
\text { Wine ratings } \\
\text { of consumers } \\
\text { with } \\
\text { summary } \\
\text { expert } \\
\text { information }\end{array}$ & $\begin{array}{l}\text { Detailed: } \\
\text { ratings } \\
\text { consumers } \\
\text { detailed } \\
\text { information }\end{array}$ & $\begin{array}{r}\text { Wine } \\
\text { of } \\
\text { with } \\
\text { expert }\end{array}$ & & \\
\hline & & & \multicolumn{3}{|c|}{ Inf. Complexity } & & \\
\hline
\end{tabular}


Table 2. Sample. Descriptive statistics.

\begin{tabular}{|c|c|c|c|c|c|c|c|c|c|c|c|}
\hline \multirow{2}{*}{$\begin{array}{l}\text { Experiment } \\
\text { Groups } \\
\text { Variables }\end{array}$} & \multirow{2}{*}{$\begin{array}{l}\text { Wine } \\
\text { professionals }\end{array}$} & \multicolumn{2}{|c|}{$\begin{array}{l}\text { Consumers with } \\
\text { no expert } \\
\text { information }\end{array}$} & \multicolumn{2}{|c|}{$\begin{array}{l}\text { Consumers with } \\
\text { detailed expert } \\
\text { information with } \\
\text { high consensus }\end{array}$} & \multicolumn{2}{|c|}{$\begin{array}{l}\text { Consumers with } \\
\text { summary expert } \\
\text { information with } \\
\text { high consensus }\end{array}$} & \multicolumn{2}{|c|}{$\begin{array}{l}\text { Consumers with } \\
\text { detailed expert } \\
\text { information with } \\
\text { low consensus }\end{array}$} & \multicolumn{2}{|c|}{$\begin{array}{l}\text { Consumers with } \\
\text { summary expert } \\
\text { information with low } \\
\text { consensus }\end{array}$} \\
\hline & & $\begin{array}{l}\text { High } \\
\text { knowl. }\end{array}$ & $\begin{array}{l}\text { Low } \\
\text { knowl. }\end{array}$ & $\begin{array}{l}\text { High } \\
\text { knowl. }\end{array}$ & $\begin{array}{l}\text { Low } \\
\text { knowl. }\end{array}$ & $\begin{array}{l}\text { High } \\
\text { knowl. }\end{array}$ & $\begin{array}{l}\text { Low } \\
\text { knowl. }\end{array}$ & $\begin{array}{l}\text { High } \\
\text { knowl. }\end{array}$ & $\begin{array}{l}\text { Low } \\
\text { knowl. }\end{array}$ & $\begin{array}{l}\text { High } \\
\text { knowl. }\end{array}$ & $\begin{array}{l}\text { Low } \\
\text { knowl. }\end{array}$ \\
\hline \multicolumn{12}{|l|}{ Age } \\
\hline Under 25 & 0 & 1 & 7 & 0 & 0 & 2 & 2 & 0 & 0 & 2 & 11 \\
\hline $26-35$ & 7 & 4 & 0 & 4 & 7 & 3 & 1 & 2 & 8 & 6 & 3 \\
\hline $36-45$ & 2 & 3 & 2 & 7 & 6 & 2 & 4 & 10 & 4 & 2 & 1 \\
\hline 46-55 & 1 & 5 & 2 & 4 & 1 & 1 & 2 & 3 & 3 & 5 & 0 \\
\hline Over 55 & 0 & 9 & 11 & 1 & 0 & 8 & 5 & 0 & 0 & 0 & 0 \\
\hline \multicolumn{12}{|l|}{ Education } \\
\hline Primary & 0 & 4 & 8 & 0 & 2 & 5 & 4 & 1 & 6 & 3 & 3 \\
\hline Secondary & 0 & 5 & 5 & 8 & 6 & 2 & 2 & 10 & 5 & 5 & 5 \\
\hline University & 5 & 4 & 3 & 3 & 6 & 3 & 2 & 2 & 4 & 3 & 0 \\
\hline Postgrad & 4 & 9 & 6 & 3 & 0 & 6 & 5 & 2 & 0 & 3 & 7 \\
\hline Other & 1 & 0 & 0 & 2 & 0 & 0 & 1 & 0 & 0 & 1 & 0 \\
\hline \multicolumn{12}{|c|}{ Wine related job } \\
\hline Yes & 10 & 4 & 2 & 2 & 1 & 3 & 1 & 0 & 0 & 1 & 0 \\
\hline No & 0 & 18 & 20 & 14 & 13 & 13 & 13 & 15 & 15 & 14 & 15 \\
\hline \multicolumn{12}{|l|}{ Wine courses } \\
\hline Yes & 10 & 9 & 0 & 7 & 2 & 7 & 0 & 4 & 1 & 4 & 0 \\
\hline No & 0 & 13 & 22 & 9 & 12 & 9 & 14 & 11 & 14 & 11 & 15 \\
\hline Total & 10 & 22 & 22 & 16 & 14 & 16 & 14 & 15 & 15 & 15 & 15 \\
\hline
\end{tabular}


Table 3: Summary of empirical analysis

\begin{tabular}{|c|c|c|c|c|}
\hline Rating & Coef. & Robust Std. Err. & $t$ & $P>t$ \\
\hline Constant Bottle1 & 4.902 & 0.222 & 22.070 & 0.000 \\
\hline Constant Bottle2 & 4.970 & 0.281 & 17.660 & 0.000 \\
\hline Constant Bottle3 & 4.879 & 0.208 & 23.410 & 0.000 \\
\hline Constant Bottle4 & 4.606 & 0.213 & 21.620 & 0.000 \\
\hline Constant Bottle5 & 4.674 & 0.224 & 20.880 & 0.000 \\
\hline Constant Bottle6 & 5.061 & 0.247 & 20.500 & 0.000 \\
\hline \multicolumn{5}{|l|}{ H1 } \\
\hline Bottle 1 Report & -0.388 & 0.250 & -1.550 & 0.122 \\
\hline Bottle 2 Report & -0.598 & 0.307 & -1.950 & 0.053 \\
\hline Bottle 3 Report & -1.049 & 0.254 & -4.130 & 0.000 \\
\hline Bottle 4 Report & -0.418 & 0.251 & -1.670 & 0.098 \\
\hline Bottle 5Report & -0.228 & 0.256 & -0.890 & 0.374 \\
\hline Bottle 6 Report & -0.581 & 0.270 & -2.150 & 0.033 \\
\hline \multicolumn{5}{|l|}{$\mathrm{H} 2$} \\
\hline Knowledge & -0.870 & 0.241 & -3.610 & 0.000 \\
\hline \multicolumn{5}{|l|}{ H3 } \\
\hline Dummy Report*Knowledge & 0.673 & 0.290 & 2.320 & 0.022 \\
\hline \multicolumn{5}{|l|}{$\mathrm{H} 4$} \\
\hline Dummy Report *Consensus & -0.045 & 0.112 & -0.400 & 0.686 \\
\hline \multicolumn{5}{|l|}{$\mathrm{H} 5$} \\
\hline Dummy Report *Complexity & -0.315 & 0.183 & -1.720 & 0.087 \\
\hline Dummy Report *Knowledge*Complexity & 0.228 & 0.218 & 1.040 & 0.298 \\
\hline \multicolumn{5}{|l|}{ Control variables } \\
\hline Man & - & - & - & - \\
\hline Woman & 0.140 & 0.154 & 0.910 & 0.365 \\
\hline Younger than 25 & - & - & - & - \\
\hline 26-35 year & -0.009 & 0.167 & -0.050 & 0.957 \\
\hline 36-45 year & 0.005 & 0.164 & 0.030 & 0.977 \\
\hline 46-55 year & 0.206 & 0.202 & 1.020 & 0.308 \\
\hline 56 or older & 0.289 & 0.199 & 1.450 & 0.148 \\
\hline Number of obs & 984 & & & \\
\hline $\mathrm{F}(22,163)$ & 446.530 & & & \\
\hline Prob > F & 0.000 & & & \\
\hline R-squared & 0.936 & & & \\
\hline Root MSE & 1.134 & & & \\
\hline
\end{tabular}


Appendix A. Detailed Report Version 1 (a detailed attribute assessment with high consensus data)

\begin{tabular}{|c|c|c|c|c|c|c|c|}
\hline & & $\begin{array}{c}\text { WINE } \\
1\end{array}$ & $\begin{array}{l}\text { WINE } \\
2\end{array}$ & $\begin{array}{c}\text { WINE } \\
3\end{array}$ & $\begin{array}{c}\text { WINE } \\
4\end{array}$ & $\begin{array}{l}\text { WINE } \\
5\end{array}$ & $\begin{array}{l}\text { WINE } \\
6\end{array}$ \\
\hline $\begin{array}{l}\text { EXPERTS' } \\
\text { OVERALL } \\
\text { RATING }\end{array}$ & $\begin{array}{c}\text { AVERAGE } \\
\text { CONSENSUS }\end{array}$ & $\begin{array}{c}4.7 \\
(9.5)\end{array}$ & $\begin{array}{c}4.7 \\
(8.2)\end{array}$ & $\begin{array}{c}3.1 \\
(7.5)\end{array}$ & $\begin{array}{c}4.6 \\
(8.8)\end{array}$ & $\begin{array}{l}5.4 \\
(8.1)\end{array}$ & $\begin{array}{l}5.1 \\
(7.2)\end{array}$ \\
\hline \multicolumn{8}{|l|}{$\begin{array}{l}\text { ECONOMIC } \\
\text { FACTORS }\end{array}$} \\
\hline Price & $\begin{array}{c}\text { AVERAGE } \\
\text { CONSENSUS }\end{array}$ & $\begin{array}{c}3 \\
(7.5)\end{array}$ & $\begin{array}{l}3.9 \\
(8.1)\end{array}$ & $\begin{array}{l}2.1 \\
(5.5)\end{array}$ & $\begin{array}{l}3.4 \\
(7.7)\end{array}$ & $\begin{array}{c}5 \\
(8.1)\end{array}$ & $\begin{array}{l}4.1 \\
(8.7)\end{array}$ \\
\hline \multicolumn{8}{|l|}{$\begin{array}{l}\text { BASIC FLAVOR } \\
\text { FACTORS. }\end{array}$} \\
\hline Acidity & $\begin{array}{c}\text { AVERAGE } \\
\text { CONSENSUS }\end{array}$ & $\begin{array}{l}4.9 \\
(9)\end{array}$ & $\begin{array}{l}4.3 \\
(9.1)\end{array}$ & $\begin{array}{l}2.8 \\
(8.6)\end{array}$ & $\begin{array}{l}4.9 \\
(8.8)\end{array}$ & $\begin{array}{l}5.5 \\
(8.2)\end{array}$ & $\begin{array}{r}4.3 \\
(8.6)\end{array}$ \\
\hline Bitterness & $\begin{array}{c}\text { AVERAGE } \\
\text { CONSENSUS }\end{array}$ & $\begin{array}{r}3.8 \\
(8.2)\end{array}$ & $\begin{array}{r}3.8 \\
(8.5)\end{array}$ & $\begin{array}{r}1.9 \\
(7.7)\end{array}$ & $\begin{array}{r}3.8 \\
(8.7)\end{array}$ & $\begin{array}{r}4.9 \\
(7.7)\end{array}$ & $\begin{array}{r}3.6 \\
(8.6)\end{array}$ \\
\hline Sweetness & $\begin{array}{c}\text { AVERAGE } \\
\text { CONSENSUS }\end{array}$ & $\begin{array}{r}3.1 \\
(8.3)\end{array}$ & $\begin{array}{r}2.5 \\
(8.1)\end{array}$ & $\begin{array}{l}1.3 \\
(8.0)\end{array}$ & $\begin{array}{l}3.2 \\
(7.8)\end{array}$ & $\begin{array}{l}5.1 \\
(7.9)\end{array}$ & $\begin{array}{l}3.1 \\
(8.3)\end{array}$ \\
\hline \multicolumn{8}{|l|}{$\begin{array}{l}\text { VISUAL } \\
\text { FACTORS. }\end{array}$} \\
\hline Transparency & $\begin{array}{c}\text { AVERAGE } \\
\text { CONSENSUS }\end{array}$ & $\begin{array}{r}5.8 \\
(9.1)\end{array}$ & $\begin{array}{r}5.9 \\
(8.5)\end{array}$ & $\begin{array}{r}4.2 \\
(9.1)\end{array}$ & $\begin{array}{r}5.8 \\
(8.5)\end{array}$ & $\begin{array}{r}6.5 \\
(7.5)\end{array}$ & $\begin{array}{r}5.6 \\
(9.0)\end{array}$ \\
\hline Color intensity & $\begin{array}{c}\text { AVERAGE } \\
\text { CONSENSUS }\end{array}$ & $\begin{array}{r}4.9 \\
(8.5)\end{array}$ & $\begin{array}{r}5.9 \\
(9.5)\end{array}$ & $\begin{array}{l}4.5 \\
(9.5)\end{array}$ & $\begin{array}{l}5.1 \\
(9.2)\end{array}$ & $\begin{array}{r}6.6 \\
(9.0)\end{array}$ & $\begin{array}{r}5.7 \\
(9.3)\end{array}$ \\
\hline \multicolumn{8}{|l|}{$\begin{array}{l}\text { AROMAS (palate } \\
\text { /nose) }\end{array}$} \\
\hline Intensity & $\begin{array}{c}\text { AVERAGE } \\
\text { CONSENSUS }\end{array}$ & $\begin{array}{r}4.1 \\
(8.5)\end{array}$ & $\begin{array}{r}4.8 \\
(9.1)\end{array}$ & $\begin{array}{r}2.9 \\
(8.1)\end{array}$ & $\begin{array}{r}4.5 \\
(9.0)\end{array}$ & $\begin{array}{r}5.4 \\
(8.5)\end{array}$ & $\begin{array}{r}4.9 \\
(8.8)\end{array}$ \\
\hline $\begin{array}{l}\text { Harmony-balance } \\
\text { of aromas }\end{array}$ & $\begin{array}{c}\text { AVERAGE } \\
\text { CONSENSUS }\end{array}$ & $\begin{array}{l}4.7 \\
(8.2)\end{array}$ & $\begin{array}{r}4.6 \\
(9.0)\end{array}$ & $\begin{array}{r}3.1 \\
(7.7)\end{array}$ & $\begin{array}{r}4.9 \\
(8.8)\end{array}$ & $\begin{array}{l}5.1 \\
(8.2)\end{array}$ & $\begin{array}{l}4.7 \\
(8.8)\end{array}$ \\
\hline $\begin{array}{l}\text { TASTE } \\
\text { SENSATIONS }\end{array}$ & & & & & & & \\
\hline $\begin{array}{l}\text { Harmony-balance } \\
\text { of flavors }\end{array}$ & $\begin{array}{c}\text { AVERAGE } \\
\text { CONSENSUS }\end{array}$ & $\begin{array}{l}4.3 \\
(8.6)\end{array}$ & $\begin{array}{l}4.7 \\
(9.1)\end{array}$ & $\begin{array}{l}2.9 \\
(7.7)\end{array}$ & $\begin{array}{l}4.5 \\
(8.6)\end{array}$ & $\begin{array}{r}5.3 \\
(8.0)\end{array}$ & $\begin{array}{r}4.6 \\
(7.3)\end{array}$ \\
\hline $\begin{array}{l}\text { Persistence of } \\
\text { flavor }\end{array}$ & $\begin{array}{c}\text { AVERAGE } \\
\text { CONSENSUS }\end{array}$ & $\begin{array}{r}4.2 \\
(8.2)\end{array}$ & $\begin{array}{r}4.9 \\
(8.5)\end{array}$ & $\begin{array}{l}2.7 \\
(8.2)\end{array}$ & $\begin{array}{l}3.8 \\
(8.9)\end{array}$ & $\begin{array}{r}5.3 \\
(8.2)\end{array}$ & $\begin{array}{r}4.3 \\
(8.8)\end{array}$ \\
\hline Tannic roughness & $\begin{array}{c}\text { AVERAGE } \\
\text { CONSENSUS }\end{array}$ & $\begin{array}{l}2.5 \\
(8.4)\end{array}$ & $\begin{array}{r}4.4 \\
(7.0)\end{array}$ & $\begin{array}{l}3.1 \\
(8.4)\end{array}$ & $\begin{array}{l}3.5 \\
(7.9)\end{array}$ & $\begin{array}{r}4.8 \\
(6.8)\end{array}$ & $\begin{array}{r}4.4 \\
(7.9)\end{array}$ \\
\hline
\end{tabular}


Appendix B. Simplified report. Version 1 (a summarized attribute assessment with high consensus data)

\begin{tabular}{|c|c|c|c|c|c|c|c|}
\hline & & $\begin{array}{c}\text { WINE } \\
1\end{array}$ & $\begin{array}{c}\text { WINE } \\
2\end{array}$ & $\begin{array}{c}\text { WINE } \\
3\end{array}$ & $\begin{array}{c}\text { WINE } \\
4\end{array}$ & $\begin{array}{c}\text { WINE } \\
5\end{array}$ & $\begin{array}{c}\text { WINE } \\
6\end{array}$ \\
\hline $\begin{array}{l}\text { EXPERTS' } \\
\text { OVERALL } \\
\text { RATING }\end{array}$ & $\begin{array}{c}\text { AVERAGE } \\
\text { CONSENSUS }\end{array}$ & $\begin{array}{c}4.7 \\
(9.5)\end{array}$ & $\begin{array}{c}4.7 \\
(8.2)\end{array}$ & $\begin{array}{c}3.1 \\
(7.5)\end{array}$ & $\begin{array}{c}4.6 \\
(8.8)\end{array}$ & $\begin{array}{c}5.4 \\
(8.1)\end{array}$ & $\begin{array}{c}5.1 \\
(7.2)\end{array}$ \\
\hline $\begin{array}{l}\text { ECONOMIC } \\
\text { FACTORS }\end{array}$ & $\begin{array}{c}\text { AVERAGE } \\
\text { CONSENSUS }\end{array}$ & $\begin{array}{c}3 \\
(7.5)\end{array}$ & $\begin{array}{l}3.9 \\
(8.1)\end{array}$ & $\begin{array}{l}2.1 \\
(5.5)\end{array}$ & $\begin{array}{l}3.4 \\
(7.7)\end{array}$ & $\begin{array}{c}5 \\
(8.1)\end{array}$ & $\begin{array}{r}4.1 \\
(8.7)\end{array}$ \\
\hline $\begin{array}{l}\text { BASIC } \\
\text { FLAVOR } \\
\text { FACTORS }\end{array}$ & $\begin{array}{c}\text { AVERAGE } \\
\text { CONSENSUS }\end{array}$ & $\begin{array}{l}4.4 \\
(9.2)\end{array}$ & $\begin{array}{l}4.5 \\
(7.9)\end{array}$ & $\begin{array}{l}2.8 \\
(8.4)\end{array}$ & $\begin{array}{l}4.1 \\
(8.1)\end{array}$ & $\begin{array}{l}5.3 \\
(8.7)\end{array}$ & $\begin{array}{r}4.1 \\
(8.7)\end{array}$ \\
\hline $\begin{array}{l}\text { VISUAL } \\
\text { FACTORS }\end{array}$ & $\begin{array}{c}\text { AVERAGE } \\
\text { CONSENSUS }\end{array}$ & $\begin{array}{l}4.8 \\
(9.3)\end{array}$ & $\begin{array}{l}5.4 \\
(9.5)\end{array}$ & $\begin{array}{l}3.5 \\
(8.6)\end{array}$ & $\begin{array}{l}4.3 \\
(8.0)\end{array}$ & $\begin{array}{l}6.1 \\
(8.1)\end{array}$ & $\begin{array}{c}4.4 \\
(8.1)\end{array}$ \\
\hline $\begin{array}{l}\text { AROMAS } \\
\text { (NOSE AND } \\
\text { PALATE) }\end{array}$ & $\begin{array}{c}\text { AVERAGE } \\
\text { CONSENSUS }\end{array}$ & $\begin{array}{l}4.2 \\
(9.1)\end{array}$ & $\begin{array}{l}4.5 \\
(8.4)\end{array}$ & $\begin{array}{l}3.5 \\
(8.0)\end{array}$ & $\begin{array}{c}4 \\
(7.7)\end{array}$ & $\begin{array}{r}5.5 \\
(7.7)\end{array}$ & $\begin{array}{c}4.1 \\
(9.2)\end{array}$ \\
\hline $\begin{array}{l}\text { TASTE } \\
\text { SENSATIONS } \\
\text { (IN THE } \\
\text { MOUTH) }\end{array}$ & $\begin{array}{c}\text { AVERAGE } \\
\text { CONSENSUS }\end{array}$ & $\begin{array}{c}4.1 \\
(9.0)\end{array}$ & $\begin{array}{r}4.8 \\
(8.9)\end{array}$ & $\begin{array}{r}3.3 \\
(7.3)\end{array}$ & $\begin{array}{c}4 \\
(8.0)\end{array}$ & $\begin{array}{r}5.4 \\
(7.4)\end{array}$ & $\begin{array}{c}4.7 \\
(8.4)\end{array}$ \\
\hline
\end{tabular}


Appendix C. Detailed Report Version 2 (a detailed attribute assessment with low consensus data, reporting one third of the high consensus in the complete report)

\begin{tabular}{|c|c|c|c|c|c|c|c|}
\hline & & $\begin{array}{c}\text { WINE } \\
1\end{array}$ & $\begin{array}{c}\text { WINE } \\
2\end{array}$ & $\begin{array}{c}\text { WINE } \\
3\end{array}$ & $\begin{array}{c}\text { WINE } \\
4\end{array}$ & $\begin{array}{c}\text { WINE } \\
5\end{array}$ & $\begin{array}{c}\text { WINE } \\
6\end{array}$ \\
\hline $\begin{array}{l}\text { EXPERTS’ } \\
\text { OVERALL } \\
\text { RATING }\end{array}$ & $\begin{array}{c}\text { AVERAGE } \\
\text { CONSENSUS }\end{array}$ & $\begin{array}{c}4.7 \\
(3.2)\end{array}$ & $\begin{array}{l}4.7 \\
(2.7)\end{array}$ & $\begin{array}{l}3.1 \\
(2.5)\end{array}$ & $\begin{array}{l}4.6 \\
(2.9)\end{array}$ & $\begin{array}{l}5.4 \\
(2.7)\end{array}$ & $\begin{array}{c}5.1 \\
(2.4)\end{array}$ \\
\hline $\begin{array}{l}\text { ECONOMIC } \\
\text { FACTORS }\end{array}$ & & & & & & & \\
\hline Price & $\begin{array}{c}\text { AVERAGE } \\
\text { CONSENSUS }\end{array}$ & $\begin{array}{c}3 \\
(2.5)\end{array}$ & $\begin{array}{l}3.9 \\
(2.7)\end{array}$ & $\begin{array}{l}2.1 \\
(1.8)\end{array}$ & $\begin{array}{l}3.4 \\
(2.6)\end{array}$ & $\begin{array}{c}5 \\
(2.7)\end{array}$ & $\begin{array}{l}4.1 \\
(2.9)\end{array}$ \\
\hline \multicolumn{8}{|c|}{ BASIC FLAVOR FACTORS. } \\
\hline Acidity & $\begin{array}{c}\text { AVERAGE } \\
\text { CONSENSUS }\end{array}$ & $\begin{array}{r}4.9 \\
(3.0)\end{array}$ & $\begin{array}{r}4.3 \\
(3.0)\end{array}$ & $\begin{array}{l}2.8 \\
(2.9)\end{array}$ & $\begin{array}{l}4.9 \\
(2.9)\end{array}$ & $\begin{array}{l}5.5 \\
(2.7)\end{array}$ & $\begin{array}{l}4.3 \\
(2.9)\end{array}$ \\
\hline Bitterness & $\begin{array}{c}\text { AVERAGE } \\
\text { CONSENSUS }\end{array}$ & $\begin{array}{l}3.8 \\
(2.7)\end{array}$ & $\begin{array}{l}3.8 \\
(2.8)\end{array}$ & $\begin{array}{l}1.9 \\
(2.6)\end{array}$ & $\begin{array}{l}3.8 \\
(2.9)\end{array}$ & $\begin{array}{l}4.9 \\
(2.6)\end{array}$ & $\begin{array}{l}3.6 \\
(2.9)\end{array}$ \\
\hline Sweetness & $\begin{array}{c}\text { AVERAGE } \\
\text { CONSENSUS }\end{array}$ & $\begin{array}{l}3.1 \\
(2.8)\end{array}$ & $\begin{array}{l}2.5 \\
(2.7)\end{array}$ & $\begin{array}{l}1.3 \\
(2.7)\end{array}$ & $\begin{array}{l}3.2 \\
(2.6)\end{array}$ & $\begin{array}{l}5.1 \\
(2.6)\end{array}$ & $\begin{array}{l}3.1 \\
(2.8)\end{array}$ \\
\hline \multicolumn{8}{|c|}{ VISUAL FACTORS. } \\
\hline Transparency & $\begin{array}{c}\text { AVERAGE } \\
\text { CONSENSUS }\end{array}$ & $\begin{array}{c}5.8 \\
(3.0)\end{array}$ & $\begin{array}{c}5.9 \\
(2.8)\end{array}$ & $\begin{array}{l}4.2 \\
(3.0)\end{array}$ & $\begin{array}{l}5.8 \\
(2.8)\end{array}$ & $\begin{array}{l}6.5 \\
(2.5)\end{array}$ & $\begin{array}{l}5.6 \\
(3.0)\end{array}$ \\
\hline Color intensity & $\begin{array}{c}\text { AVERAGE } \\
\text { CONSENSUS }\end{array}$ & $\begin{array}{l}4.9 \\
(2.8)\end{array}$ & $\begin{array}{l}5.9 \\
(3.2)\end{array}$ & $\begin{array}{c}4.5 \\
(3.2)\end{array}$ & $\begin{array}{l}5.1 \\
(3.1)\end{array}$ & $\begin{array}{l}6.6 \\
(3.0)\end{array}$ & $\begin{array}{l}5.7 \\
(3.1)\end{array}$ \\
\hline \multicolumn{8}{|c|}{ AROMAS (palate /nose) } \\
\hline Intensity & $\begin{array}{c}\text { AVERAGE } \\
\text { CONSENSUS }\end{array}$ & $\begin{array}{c}4.1 \\
(2.8)\end{array}$ & $\begin{array}{c}4.8 \\
(3.0)\end{array}$ & $\begin{array}{r}2.9 \\
(2.7)\end{array}$ & $\begin{array}{l}4.5 \\
(3.0)\end{array}$ & $\begin{array}{l}5.4 \\
(2.8)\end{array}$ & $\begin{array}{l}4.9 \\
(2.9)\end{array}$ \\
\hline $\begin{array}{l}\text { Harmony-balance } \\
\text { of aromas }\end{array}$ & $\begin{array}{c}\text { AVERAGE } \\
\text { CONSENSUS }\end{array}$ & $\begin{array}{l}4.7 \\
(2.7)\end{array}$ & $\begin{array}{l}4.6 \\
(3.0)\end{array}$ & $\begin{array}{l}3.1 \\
(2.6)\end{array}$ & $\begin{array}{l}4.9 \\
(2.9)\end{array}$ & $\begin{array}{l}5.1 \\
(2.7)\end{array}$ & $\begin{array}{l}4.7 \\
(2.9)\end{array}$ \\
\hline \multicolumn{8}{|c|}{ TASTE SENSATIONS } \\
\hline $\begin{array}{l}\text { Harmony-balance } \\
\text { of flavors }\end{array}$ & $\begin{array}{c}\text { AVERAGE } \\
\text { CONSENSUS }\end{array}$ & $\begin{array}{r}4.3 \\
(2.9)\end{array}$ & $\begin{array}{c}4.7 \\
(3.0)\end{array}$ & $\begin{array}{c}2.9 \\
(2.6)\end{array}$ & $\begin{array}{l}4.5 \\
(2.9)\end{array}$ & $\begin{array}{l}5.3 \\
(2.7)\end{array}$ & $\begin{array}{l}4.6 \\
(2.4)\end{array}$ \\
\hline $\begin{array}{l}\text { Persistence of } \\
\text { flavor }\end{array}$ & $\begin{array}{c}\text { AVERAGE } \\
\text { CONSENSUS }\end{array}$ & $\begin{array}{l}4.2 \\
(2.7)\end{array}$ & $\begin{array}{l}4.9 \\
(2.8)\end{array}$ & $\begin{array}{l}2.7 \\
(2.7)\end{array}$ & $\begin{array}{r}3.8 \\
(3.0)\end{array}$ & $\begin{array}{l}5.3 \\
(2.7)\end{array}$ & $\begin{array}{l}4.3 \\
(2.9)\end{array}$ \\
\hline Tannic roughness & $\begin{array}{c}\text { AVERAGE } \\
\text { CONSENSUS }\end{array}$ & $\begin{array}{l}2.5 \\
(2.8)\end{array}$ & $\begin{array}{l}4.4 \\
(2.3)\end{array}$ & $\begin{array}{l}3.1 \\
(2.8)\end{array}$ & $\begin{array}{l}3.5 \\
(2.6)\end{array}$ & $\begin{array}{l}4.8 \\
(2.3)\end{array}$ & $\begin{array}{r}4.4 \\
(2.6)\end{array}$ \\
\hline
\end{tabular}


Appendix D. Simplified report. Version 2 (a summarized attribute assessment with low consensus data, reporting one third of the high consensus in the simplified report).

\begin{tabular}{|c|c|c|c|c|c|c|c|}
\hline & & $\begin{array}{c}\text { WINE } \\
1\end{array}$ & $\begin{array}{c}\text { WINE } \\
2\end{array}$ & $\begin{array}{c}\text { WINE } \\
3\end{array}$ & $\begin{array}{c}\text { WINE } \\
4\end{array}$ & $\begin{array}{c}\text { WINE } \\
5\end{array}$ & $\begin{array}{c}\text { WINE } \\
6\end{array}$ \\
\hline $\begin{array}{l}\text { EXPERTS' } \\
\text { OVERALL } \\
\text { RATING }\end{array}$ & $\begin{array}{c}\text { AVERAGE } \\
\text { CONSENSUS }\end{array}$ & $\begin{array}{l}4.7 \\
(3.2)\end{array}$ & $\begin{array}{c}4.7 \\
(2.7)\end{array}$ & $\begin{array}{l}3.1 \\
(2.5)\end{array}$ & $\begin{array}{c}4.6 \\
(2.9)\end{array}$ & $\begin{array}{l}5.4 \\
(2.7)\end{array}$ & $\begin{array}{l}5.1 \\
(2.4)\end{array}$ \\
\hline $\begin{array}{l}\text { ECONOMIC } \\
\text { FACTORS }\end{array}$ & $\begin{array}{c}\text { AVERAGE } \\
\text { CONSENSUS }\end{array}$ & $\begin{array}{c}3 \\
(2.5)\end{array}$ & $\begin{array}{l}3.9 \\
(2.7)\end{array}$ & $\begin{array}{l}2.1 \\
(1.8)\end{array}$ & $\begin{array}{l}3.4 \\
(2.5)\end{array}$ & $\begin{array}{c}5 \\
(2.5)\end{array}$ & $\begin{array}{l}4.1 \\
(2.9)\end{array}$ \\
\hline $\begin{array}{l}\text { BASIC } \\
\text { FLAVOR } \\
\text { FACTORS }\end{array}$ & $\begin{array}{c}\text { AVERAGE } \\
\text { CONSENSUS }\end{array}$ & $\begin{array}{l}4.4 \\
(3.0)\end{array}$ & $\begin{array}{l}4.5 \\
(2.6)\end{array}$ & $\begin{array}{l}2.8 \\
(2.8)\end{array}$ & $\begin{array}{l}4.1 \\
(1.3)\end{array}$ & $\begin{array}{l}5.3 \\
(2.9)\end{array}$ & $\begin{array}{l}4.1 \\
(3.2)\end{array}$ \\
\hline $\begin{array}{l}\text { VISUAL } \\
\text { FACTORS }\end{array}$ & $\begin{array}{c}\text { AVERAGE } \\
\text { CONSENSUS }\end{array}$ & $\begin{array}{r}4.8 \\
(3.1)\end{array}$ & $\begin{array}{l}5.4 \\
(3.1)\end{array}$ & $\begin{array}{l}3.5 \\
(2.8)\end{array}$ & $\begin{array}{l}4.3 \\
(2.6)\end{array}$ & $\begin{array}{l}6.1 \\
(2.7)\end{array}$ & $\begin{array}{l}4.4 \\
(2.7)\end{array}$ \\
\hline $\begin{array}{l}\text { AROMAS } \\
\text { (NOSE AND } \\
\text { PALATE) }\end{array}$ & $\begin{array}{c}\text { AVERAGE } \\
\text { CONSENSUS }\end{array}$ & $\begin{array}{l}4.2 \\
(3.0)\end{array}$ & $\begin{array}{l}4.5 \\
(2.8)\end{array}$ & $\begin{array}{l}3.5 \\
(2.6)\end{array}$ & $\begin{array}{c}4 \\
(2.5)\end{array}$ & $\begin{array}{l}5.5 \\
(2.5)\end{array}$ & $\begin{array}{l}4.1 \\
(3.0)\end{array}$ \\
\hline $\begin{array}{l}\text { TASTE } \\
\text { SENSATIONS } \\
\text { (IN THE } \\
\text { MOUTH) }\end{array}$ & $\begin{array}{c}\text { AVERAGE } \\
\text { CONSENSUS }\end{array}$ & $\begin{array}{l}4.1 \\
(3.0)\end{array}$ & $\begin{array}{l}4.8 \\
(2.9)\end{array}$ & $\begin{array}{l}3.3 \\
(2.4)\end{array}$ & $\begin{array}{c}4 \\
(2.6)\end{array}$ & $\begin{array}{l}5.4 \\
(2.4)\end{array}$ & $\begin{array}{r}4.7 \\
(2.8)\end{array}$ \\
\hline
\end{tabular}


${ }^{\mathrm{i}}$ In this knowledge assessment, we use three different dimensions of knowledge: subjective knowledge, objective knowledge and familiarity (Park, et al., 1994). By subjective knowledge, we mean a subject's personal perception or assessment of what they know and how much they know about a product category (Bettman and Park, 1980; Johnson and Russo, 1984; Brucks, 1985; Park et al., 1994). This type of knowledge is measured on a scale of 1-7 and includes items such as: "How do you rate your knowledge of wine?” Objective knowledge is based on the content and organization of the information stored in the memory, that is, what the subject actually knows about a type of product (Brucks, 1985; Sujan, 1985; Rao and Monroe, 1988). To test this we asked questions such as: "Which of the following wines is not a fortified wine?" Finally, the term "familiarity" is the one usually used to represent experience with a product category (Bettman and Park, 1980; Park and Lessig, 1981; Punj and Staelin, 1983). To gauge familiarity, we asked subjects to state their average wine consumption per month in liters. In this study, we attribute a high level of wine knowledge to those consumers who award themselves a wine knowledge score of 4 or more, who answer the technical question correctly and who consume more than $4 \mathrm{l}$. of wine per month. The rest are attributed a low level of wine knowledge. 